A.N. LARIN, $\mathrm{PhD} /$ докт. техн. наук А.Н. ЛАРИН ${ }^{1}$

A.A. LARIN, $\mathrm{PhD} /$ канд. техн. наук А.А. ЛАРИН ${ }^{2}$ I.L. USHAPIVSKY / И.Л. УЩАПИВСКИЙ ${ }^{3}$

Przyjęty/Accepted/Принята: 25.03.2014;

Zrecenzowany/Reviewed/Рецензирована: 05.06.2014;

Opublikowany/Published/Опубликована: 30.06 .2014

\title{
EXPERIMENTAL INVESTIGATIONS OF VIBRATIONS OF CENTRIFUGAL FIRE PUMP WITH THE DEFECT (UNFASTENED SHAFT IN A BEARING SEAT)
}

\section{Экспериментальные исследования вибраций центробежного пожарного насоса с дефектом (прослабленная посадка вала в подшипниках)}

\begin{abstract}
Objective: The paper deals with the experimental investigations of the vibrations of the centrifugal fire pump with a hidden defect. The aim of the work is to identify the vibrational symptoms which accompany the operation of a fire pump with a defect (unfastened shaft in a bearing seat). This information is applicable for the technical diagnostics of the fire pumps in operation.

Project and methods: The research consisted in a set of experimental tests of a centrifugal pump installed on the active fire engine. The experiments were carried out with the application of the measurement system "Ultra-V-I". The system has a valid certificate of state metrological certification, issued in Ukraine, and allows to make measurements of vibration acceleration of the investigated object. All signals were spectrally analysed. The Fast Fourier Transform (FFT) was used for these procedures. A spectral analysis for transient regimes of vibrations was carried out with the application of short-time Fourier transform.

Results: The changes in the spectrum and orientation of vibrations fire pump with the mentioned type of defect were identified. The analysis of the spectra of vibrations at the frequency of excitation of $2000 \mathrm{rpm}$ in the vertical direction shows strong domination of 7 harmonic $(233 \mathrm{~Hz})$. Besides, the spectrum involves first $(33.3 \mathrm{~Hz})$, third $(99 \mathrm{~Hz})$ and fourth $(133 \mathrm{~Hz})$ harmonics of rotor rotation. However, the most important phenomenon consists in the presence of fraction harmonics in the spectrum, which in turn indicates system nonlinearities caused by loosening and contact impacts. These harmonics are 0.5 and 3.5 harmonics of rotor rotation $(16.5 \mathrm{~Hz}$ and $116.6 \mathrm{~Hz})$. A quantitative comparison shows that the largest vibration level is observed in the axial direction and the smallest one is observed in the horizontal direction. The comparison of vibrations of the defected and non-defected fire pumps shows that the defect makes an axial direction weaker and it leads to increasing axial vibration acceleration up to $80 \%$. Vibrations in other directions are approximately the same in case of defected and non-defected pumps. Changes in the orientation angle of the vibrations ellipse trajectory were identified. Conclusions: The information about vibrational symptoms of the analysed type of hidden defect is useful in fire pumps technical diagnostics. This method will improve the quality of systems technical check-ups as well as their preventive maintenance. This in turn will contribute to the decrease in the amount of firefighting equipment left standing idle due to untimely repair works as well as prevent sudden failures of the utilised pumps.
\end{abstract}

Keywords: fire pump, centrifugal pump, technical diagnostics, vibrational symptoms Type of article: case study - analysis of actual events

\footnotetext{
${ }^{1}$ National University of Civil Defence of Ukraine, address: Ukraine, 61023, Kharkiv, str. Chernishevskaya, 94, e-mail: o.m.larin@ gmail.com; percentage contribution $-40 \%$.

${ }^{2}$ National Technical University "Kharkiv Polytechnical Institute”; address: Ukraine, 79000, Lviv, Kleparivska St., 35; e-mail: AlexeyA. Larin@gmail.com; percentage contribution-30\%.

${ }^{3}$ Chief Directorate of the State Emergency Service of Ukraine in the Lviv region; address: Ukraine, 79008, Lviv, vul. Podvalnaya, 6; e-mail: ipovx@i.ua; percentage contribution-30\%.
} 


\title{
Аннотация
}

Цель. В статье рассматриваются экспериментальные исследования колебаний центробежного пожарного насоса, который имеет скрытый дефект. Работа посвящена идентификации колебательных симптомов, которые сопровождают эксплуатацию пожарного насоса с дефектом (ослабленная посадка вала в подшипниковом узле). Такая информация может быть использована для технической диагностики пожарного насоса в эксплуатацию.

Проект и методы. Данные исследования представляют экспериментальные тесты, которые были сделаны с центробежным насосом, который установлен на действующей пожарной машине. Эксперименты проводились на базе системы измерения «Ультра- VI», которая имеет действительное свидетельство о государственной метрологической аттестации в Украине и позволяет производить измерение виброускорений в точке исследуемого объекта. Все полученные сигналы были спектрально проанализированы, с применением быстрого преобразования Фурье (FFT) для стационарных сигналов, а для переходных режимов были проведены оконные преобразования Фурье.

Результаты. Определены изменение в спектре и в ориентации колебаний пожарного насоса с указанным типом дефекта. Анализ спектров колебаний на частоте возбуждения 2000 оборотов в минуту в вертикальном направлении показывает сильное доминирование 7 гармоники ( 233 Гц). Кроме того, в спектре существует первый (33,3 Гц), третий (99 Гц) и четвертый (133 Гц) гармоник вращения ротора. Тем не менее, наиболее важным явлением есть присутствие дробных гармоник в спектре, что указывает на наличие нелинейности в системе, вызванной наличием зазоров и контактных взаимодействий. Это гармоники 0,5 и 3,5 кратности вращения ротора (16,5 Гц и 116,6 Гц). Количественное сравнение показывает, что наибольший уровень вибрации наблюдается в осевом направлении и является наименьшим в горизонтальном направлении. Сравнение колебаний дефектного и недефектного пожарного насоса. Показано, что дефект делает слабее осевое направление и это приводит к увеличению осевых колебаний по ускорению до $80 \%$. Вибрации в других направлениях остались примерно на том же уровне для дефектных и не дефектных насосов. Также было определено явления изменение угла ориентации эллипса траектории колебаний.

Выводы. Вибрационные симптомы анализируемого типа скрытых дефектов могут быть использованы в процедурах технической диагностики пожарных насосов. Использование этого метода позволит улучшить систему технического осмотра и профилактического обслуживания, что, с одной стороны, приводит к уменьшению простоя пожарной техники в результате несвоевременных ремонтных работ, а с другой стороны позволит предотвратить внезапное отказы насосов в эксплуатации .

Ключевые слова: пожарный насос, центробежный насос, техническая диагностика, вибрационные симптомы Вид статьи: исследования случая - анализ реальных событий

\begin{abstract}
Abstrakt
Cel: W artykule omówiono badania eksperymentalne wibracji pompy odśrodkowej, w której stwierdzono ukrytą wadę. Celem pracy jest określenie charakterystyk drgań mechanicznych, które towarzyszą pracy pompy z defektem (luz w gnieździe łożyska). Wiedza ta ma zastosowanie dla diagnostyki stanu technicznego użytkowanej pompy pożarniczej.

Projekt i metody: Omawiana analiza polegała na wykonaniu szeregu testów eksperymentalnych na odśrodkowej pompie pożarniczej zamontowanej w uruchomionym samochodzie pożarniczym. Eksperymenty przeprowadzono z wykorzystaniem systemu pomiarowego „Ultra-V-1”, posiadającym ważny państwowy certyfikat metrologiczny wydany na Ukrainie i pozwalającym na wykonanie pomiarów przyspieszenia wibracji badanego urządzenia. Wszystkie sygnały poddano analizie widmowej z wykorzystaniem szybkiej transformacji Fourier. Analiza widmowa dla przebiegów przejściowych wibracji była dokonana przy użyciu krótko-czasowej transformaty Fouriera. Wyniki: Określono zmiany w widmie i kierunku wibracji pompy pożarniczej z danym typem defektu. Analiza widmowa wibracji przy częstotliwości wzbudzenia na poziomie 2000 obrotów na minutę w kierunku pionowym wykazuje silną dominację siódmej harmonicznej $(233 \mathrm{~Hz})$. Ponadto w widmie obecne są pierwsza $(33,3 \mathrm{~Hz})$, trzecia $(99 \mathrm{~Hz})$ i czwarta $(133 \mathrm{~Hz})$ harmoniczne obrotu wirnika. Niemniej jednak najważniejszym odnotowanym zjawiskiem jest obecność dodatkowych składowych harmonicznych w spektrum dla niskich częstotliwości, co wskazuje na nieliniowość systemu, spowodowaną poluzowaniami i oddziaływaniami kontaktowymi. Są to harmoniczne 0,5 i 3,5 częstotliwości obrotu wirnika $(16,5 \mathrm{~Hz}$ i 116,6 Hz). Na podstawie analizy porównawczej stwierdzono, iż największy poziom wibracji ma miejsce w kierunku osiowym, a najmniejszy - w kierunku horyzontalnym. Porównanie wibracji pompy pożarniczej z defektem i bez defektu wykazało, że defekt osłabia kierunek osiowy, a to powoduje zwiększenie przyśpieszenia drgań osiowych do $80 \%$. Wibracje o innych kierunkach były zbliżone do siebie w przypadku pomp sprawnych i z uszkodzeniem. W toku badań zauważono zjawisko zmiany kąta orientacji trajektorii eliptycznej drgań.

Wnioski: Przeprowadzone badania dotyczące analizy zmian drgań mechanicznych pompy odśrodkowej zukrytym defektem. Otrzymane wyniki mogą zostać wykorzystane w procedurach diagnostyki technicznej pomp gaśniczych. Wykorzystanie tej metodyki badawczej przyczyni się do polepszenia przeglądów technicznych i zabiegów profilaktycznych, co z jednej strony wpłynie na zmniejszenie zastoju będącego skutkiem przeprowadzania prac naprawczych w nieodpowiednim czasie, a z drugiej strony pozwoli zapobiegać nagłym awariom użytkowanych pomp.
\end{abstract}

Słowa kluczowe: pompa pożarnicza, pompa odśrodkowa, diagnostyka techniczna, symptomy wibracji Typ artykułu: studium przypadku - analiza zdarzeń rzeczywistych

\section{Introduction}

One of the most important elements of the emergency response divisions equipment is the fire engine with a centrifugal pump. Extreme operation conditions together with the long-term utilisation substantially increase the probability of hidden defects in the centrifugal fire pumps. These defects may significantly decrease the effi- ciency of the operational activities of the emergency response divisions, since they can lead to a sudden failure or negative influence on the fire-pump performance characteristics, such as discharge head, for instance. A current system of fire pump reliability control is based on the system of technical check-ups and preventive maintenance (repair). This system is effective if qualitative dia- 
gnostic methods exist, especially without disassembling of the pump which is under examination.

The experience in the area of fire pump operation indicates that common defects usually lead to the higher vibration levels during the pump operation. Thus, vibration diagnostics can be used as a good tool for identification of technical state of centrifugal fire pumps, as it is commonly used [1] for the technical diagnostics of different rotor machines (turbines, compressors and etc).

\section{Testing technique}

The methodology of experimental studies is based on a series of measurements which allow defining a regularity of changes in vibration parameters caused by the presence of the hidden defects. Thus, a comparative analysis of changes in the dynamics of the systems with and without the defect provides a possibility to define hidden defects symptoms. In consequence, it provides us with tools for diagnosis of the device's technical state.

\section{Experiment conditions and facilities}

In the work, the experimental tests have been done with the centrifugal pump, which has been installed on an active fire engine.

Experiments were carried out on the base of a measurement system "Ultra-V-I" [2,3], which has been developed at the Department of the Dynamics and Strength of Machines of the National Technical University "Kharkiv Polytechnic Institute" (Kharkiv, Ukraine). The measuring system consists of (fig. 1): a detector of vibration accelerations, an analogue-to-digital converter (ADC) and a portable computer. "Ultra-V-I" has a valid certificate of state metrological certification and allows to make a measurement of vibration acceleration at the point of investigated object. Some details of experiments study facilities are presented in the paper [4].

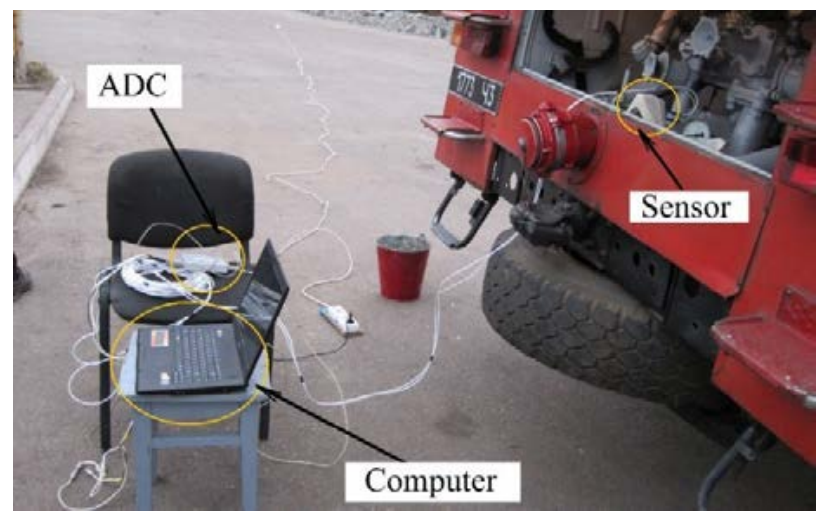

Fig. 1. Measurement system "Ultra-V-I" during the fire-pump vibration tests

The detector of vibration accelerations was equipped with the MEMS sensor ADXL250 (Analog Device, USA). This is a capacitive sensor that allows to carry out measurements of the accelerations with amplitudes in the range from 0.5 to $40 \mathrm{~m} / \mathrm{s}^{2}$ and in the frequency range from 1 to $400 \mathrm{~Hz}$. The measurements have been carried out on the body of a suction pipe of the fire pump (fig. 1) in 3 directions: axial $(\mathrm{Z})$, vertical $(\mathrm{Y})$ and horizontal $(\mathrm{X})$. The registration of the vibro-acceleration signals were carried out simultaneously in 3 dimensions with sampling frequency of $25 \mathrm{kHz}$. A circumferential velocity of rotor rotation was also measured concurrently to the main signals.

\section{Vibration analysis of the non-defected centrifugal fire pump}

The analysis deals with an experimental study of vibration occurring during the operation of the fire pump PN- 40UV that has no defects. The study of pump vibrations has been carried out on the most loaded regime, that provides a pump with an opportunity to realise different dynamic peculiarities.

The Measurements have been carried out on the body of the suction pipe of the fire pump. During these tests, an angular velocity of rotor was set near the maximum operational value that was slightly more than $2000 \mathrm{rpm}$. It should be noted that the angular velocity of the pump rotor could not be precisely fixed due to the presence of irregularity of the engine motion. Moreover, the angular velocity of the pump is controlled manually, so a human element is always present.

Therefore, it is necessary to control the angular velocity of the pump rotor rotation during measurements. It was decided to use frequency counter during the current investigation. The counter was installed at the connection of the pump rotor with a fire engine shaft. The data from frequency counter have been transmitted to the ADC and recorded on a computer in real time.

Fig. 2, a shows a typical realisation of time depending changing of the rotor angular velocity during the test. Average frequency was $\langle\omega\rangle=37.73 \mathrm{~Hz}$ that corresponds to $2264 \mathrm{rpm}$. Variations in the frequency was observed in the range from $35.67 \mathrm{~Hz}$ to $39 \mathrm{~Hz}(2140 \mathrm{rpm}-2340 \mathrm{rpm})$ with dispersion $\sigma_{\omega}^{2}=0.71 \mathrm{~Hz}^{2}$.

a
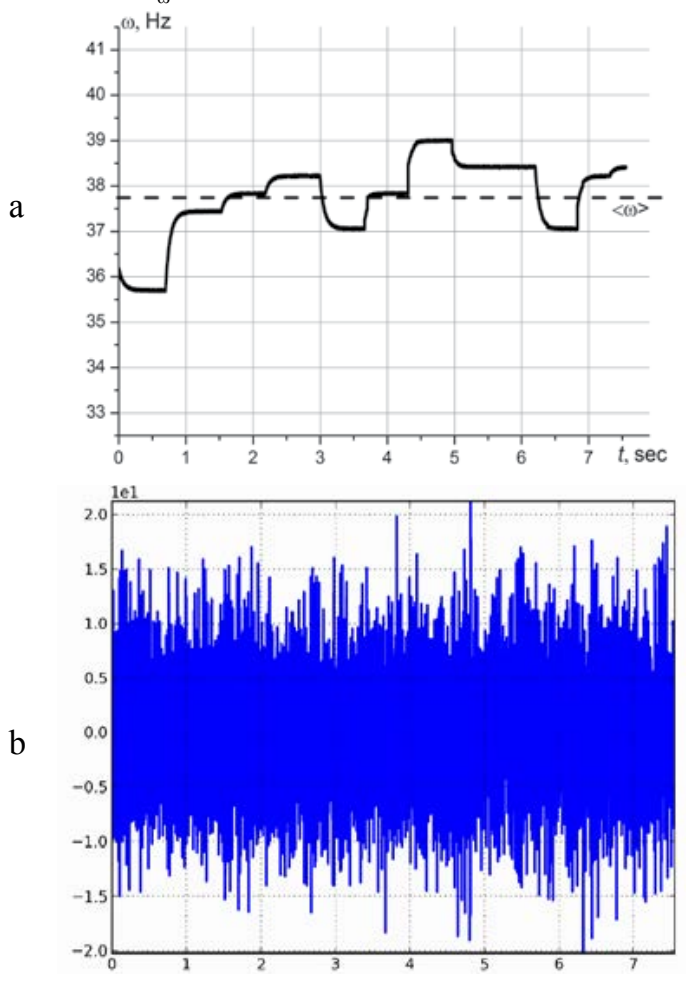

Fig. 2. A typical obtained signals during the tests of fire pump vibration a - time varying angular velocity; $\mathrm{b}$ - recorded vibration acceleration signal 
Fig. $2 \mathrm{~b}$ presents vibrational acceleration obtained in the vertical direction at the measurement point. A presence of the random fluctuations and polyharmonic nature in the signal can be observed. At the same time, the signal has no outliers, periodic impacts or other evident signal distortions. This confirms the absence of the defects in the pump and its well performed assembling. Analogous tests with the over values of pump rotor angular velocities have been carried out to obtain more detailed information about the vibrational processes. Generalization of these results can be obtained by special tests, when vibrational signal is analyzed during continuous gradual increasing of the frequency of excitation. So, the test was made with the pump that operates with the angular velocity, which is gradually increased from $800 \mathrm{rpm}$ to $2100 \mathrm{rpm}$.

The obtained signals show dependence on time of angular velocity of the pump rotor (Fig. 3,a), and vibrational acceleration (Fig. 3,b). The test was held for 30 seconds.

All the obtained signals were spectrally analyzed. A Fast Fourier Transform (FFT) is used for these procedures $[5,6]$. A vibration acceleration signal, which was obtained at the test with continuous excitation frequency increasing, was analyzed using spectrograms [7]. The signal was divided into separate fragments (windows). FFT analysis has been carried out with the signal fragment on each window. The map of spectrums has been built in the next step. The axis $\mathrm{X}$ of spectrum map presents the rotor angular velocity (or the equivalent time of test process), the axis Y corresponds to the frequency of obtained vibrations and the different colours shows the level of the amplitude at these frequencies (the largest amplitude in black and the smallest one in white). This procedure is called short-time Fourier transform and resulting map is called spectrogram.

The width of the window was set to 0.5 seconds. This value on the one hand is sufficient to obtain correct results with FFT transform within each window (lowest operating frequency of the signal corresponds to $800 \mathrm{rpm}$, so equal to $13.3 \mathrm{~Hz}$, that means that at least 10 periods analy- sed on each window). On the other hand, this width of the window allows to get results in more than 60 windows at the signal and obtain a continuous field of changing of the vibration spectrum over the time with increasing frequency of load.

Fig. 4 presents vibration spectra at the fixed value of the pump rotor angular velocity $(2000 \mathrm{rpm})$ and spectrograms for the vibration accelerations in three different directions. It should be noted that high harmonics have essential amplitudes in the spectrums of pump vibrations that even exceeded first based harmonic. It has become apparent especially for the 7 harmonic. This harmonic dominates all others in spectrums across the range of frequency of perturbation, especially for vertical and axial directions.

Existence and domination of 7 harmonics are associated with turbulent flows in the chamber of the pump that forms near the edges of driven wheel blades. The pump driven wheel has 7 blades.

A quantitative comparison shows that the largest vibration level is observed in the vertical direction and the smallest one is observed in the horizontal direction.

A detailed analysis of the orientation of vibration at the point of the pump can be made from the spatial trajectory of the acceleration vector. Corresponding results are shown in the Fig. 5.

All projections of trajectory form elliptic shapes. A major axis of the ellipse of the YZ projection of the trajectory of the vibration acceleration vector shows an inclination from the axial direction. The angle of the inclination is around $55^{\circ}$.

\section{Investigations of the fire pump vibrations that has unfasten shaft in a bearing seat}

A defect consisting in the unfastened shaft installation in a bearing seat is a widespread imperfection that accompanies the centrifugal fire pumps in operation.

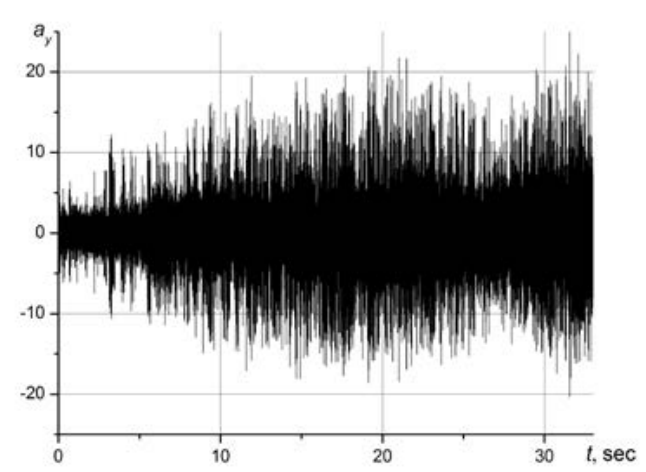

Fig. 3. The test of the pump vibration with the continuous gradual increasing of the frequency of excitation a - registered signal from the frequency counter (rotor angular velocity in time); $\mathrm{b}$ - registered vibration acceleration signal in the vertical direction 


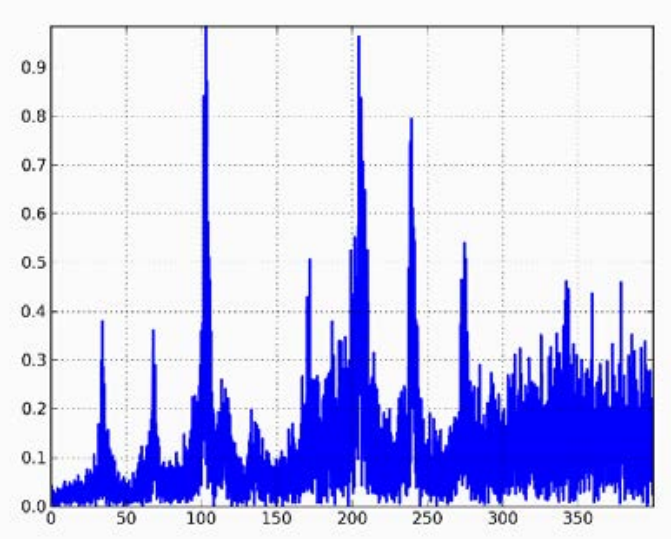

a

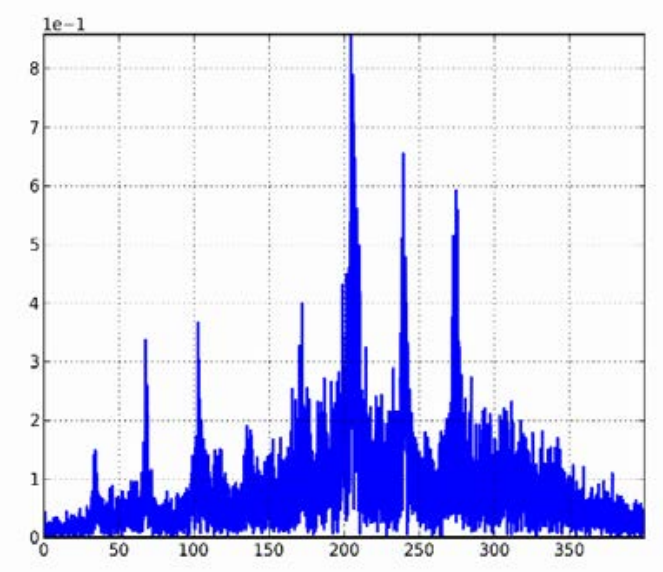

$\mathrm{C}$

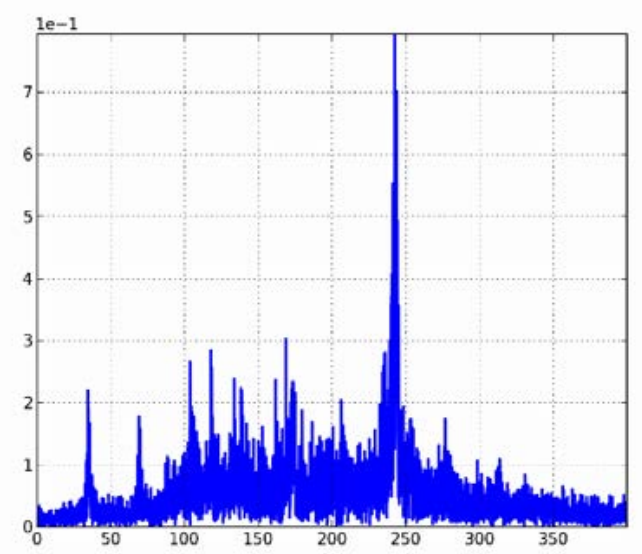

e

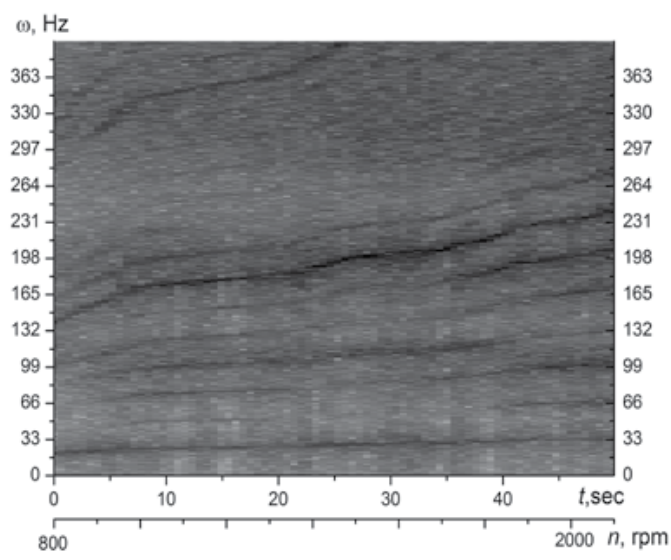

b

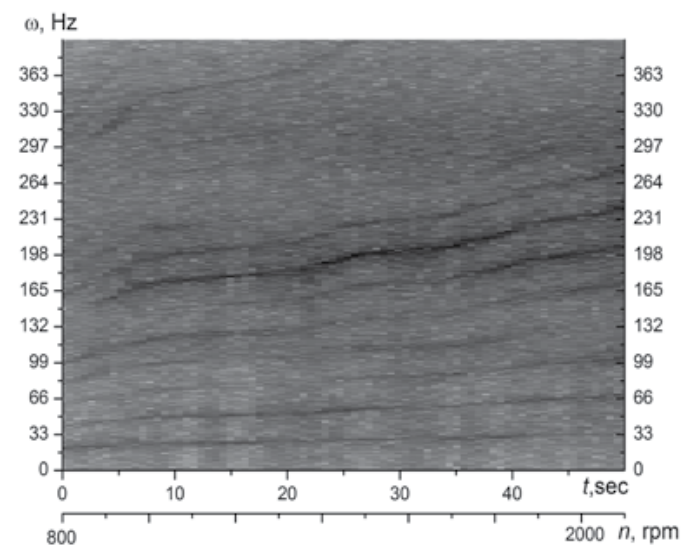

d

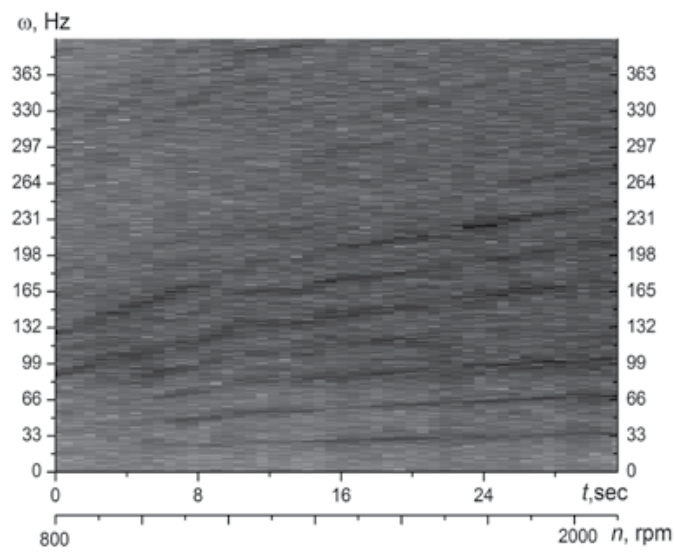

$\mathrm{f}$

Fig. 4. Spectrums (a, c, e) and spectrograms (b, d, f) of vibration accelerations of the fire pump in the vertical (a, b), the axial (c, d) and horizontal (e, f) directions

The shaft which has a smaller radius on $0.03 \mathrm{~mm}$ at the place of his landing on the first bearing was installed into a new non-defected fire pump in order to study vibrations of the pump with only unfastened shaft defect inside it.

Spectrums of pump vibration at rotor angular velocity of $2000 \mathrm{rpm}$ and spectrograms at different frequencies of excitation are shown in Fig. 6.
An analysis of vibrations at the frequency of excitation of $2000 \mathrm{rpm}$ in the vertical direction which is presented on the Fig. 6, a shows a strong domination of 7 harmonic $(233 \mathrm{~Hz})$.

Besides it, in the spectrum exists first $(33.3 \mathrm{~Hz})$, third $(99 \mathrm{~Hz})$ and fourth $(133 \mathrm{~Hz})$ harmonics of rotor rotation. However, the most important phenomenon is in the pre- 


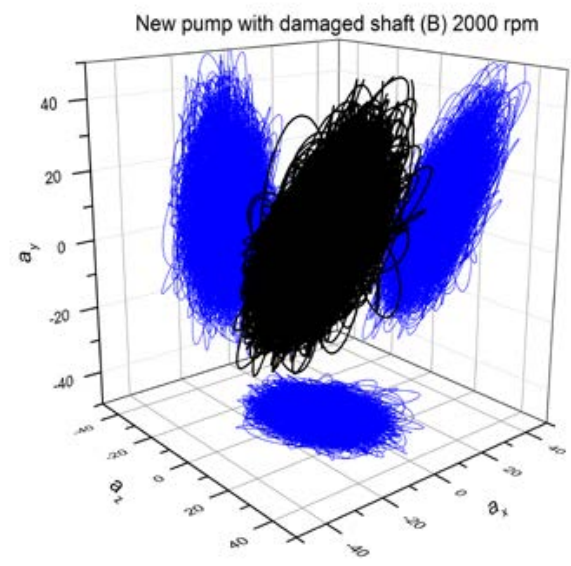

a



$\mathrm{c}$

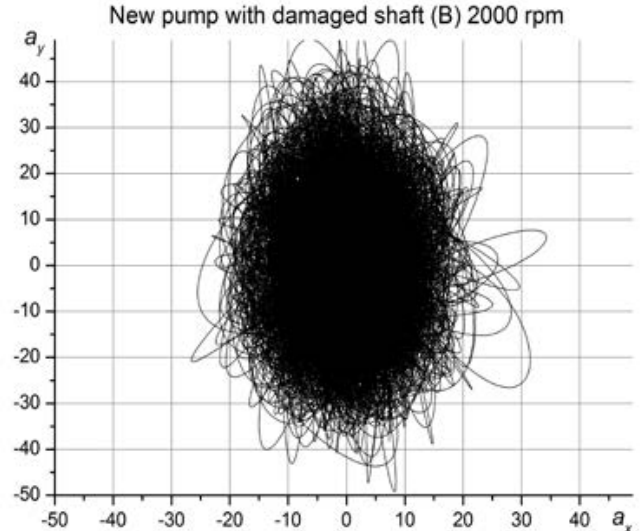

b

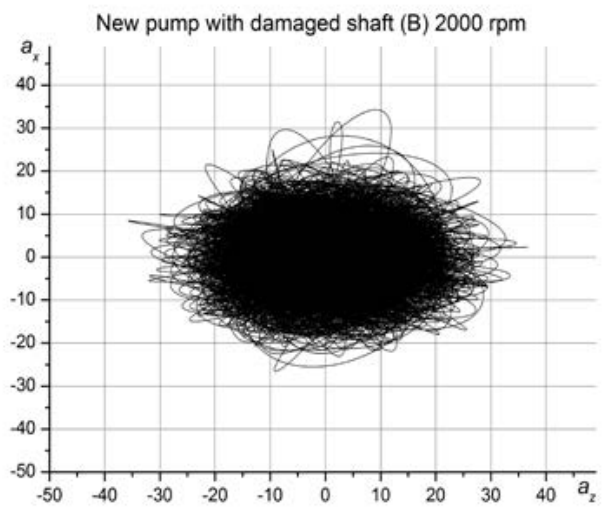

d

Fig. 5. Spatial trajectory of vibration acceleration vector (pump rotor angular velocity is about $2000 \mathrm{rpm}$ )

(a) - the trajectory in space, $(\mathrm{b}, \mathrm{c}, \mathrm{d})$ - its $\mathrm{XY}$; YZ; XZ projections

sence of fraction harmonics in the spectrum, which indicates the presence of system nonlinearities caused by the presence of looseness and contact impacts. These harmonics are 0.5 and 3.5 harmonics of rotor rotation $(16.5 \mathrm{~Hz}$ and $116.6 \mathrm{~Hz}$ ).

The same result can be seen on the spectrogram, which is shown in Fig. 6,b. The analysis of presented measurements indicates a significant domination of the 1st (main) and 7 th harmonics of rotor rotation.

Besides, the presence in the spectrum of fractional harmonics is also confirmed. The harmonic of the 0.5 of rotor rotation is observed in the all range of frequency of excitation. The harmonic with frequency 3.5 of rotor rotation appears only at high levels of vibration that is at the highest frequencies of excitation.

Analysis of spectrum and spectrogram for vibrations in the axial direction are close to the corresponding spectrum and spectrogram of non-defected fire pump vibrations at the appropriate regime. The harmonic with the frequency of 0.5 of rotor rotation is also presented in the spectrogram of vibrations in the axial direction.

A quantitative comparison shows that the largest vibration level is observed in the axial direction and the smallest one is in the horizontal direction. A comparison of vibrations of the defected and non-defected fire pump showed that defect makes the axial direction weaker and this leads to increasing axial vibration acceleration up to $80 \%$. Vibrations in other directions are approximately at the same level when it comes to defected and non-defected pumps.

Another feature that accompanies the unfastened shaft defect are changes in the spatial form of vibration. Indeed, the presence of such defect leads to the rearrangement of system stiffness that becomes a cause of the changing of vibration modes. An analysis of this phenomenon can be realised relying on the comparison of the spatial trajectory of the vector of vibration acceleration for defected and non-defected pumps. 


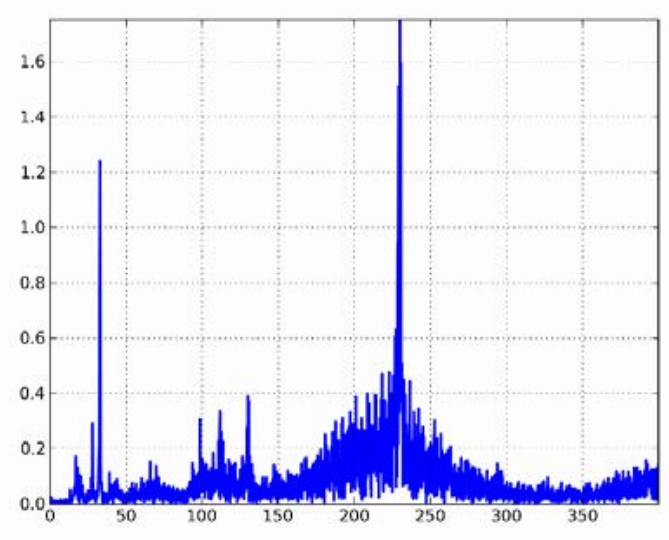

a



c

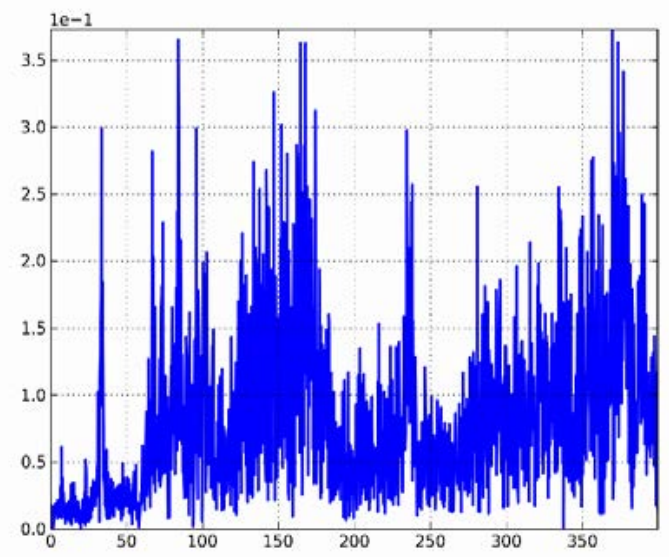

e

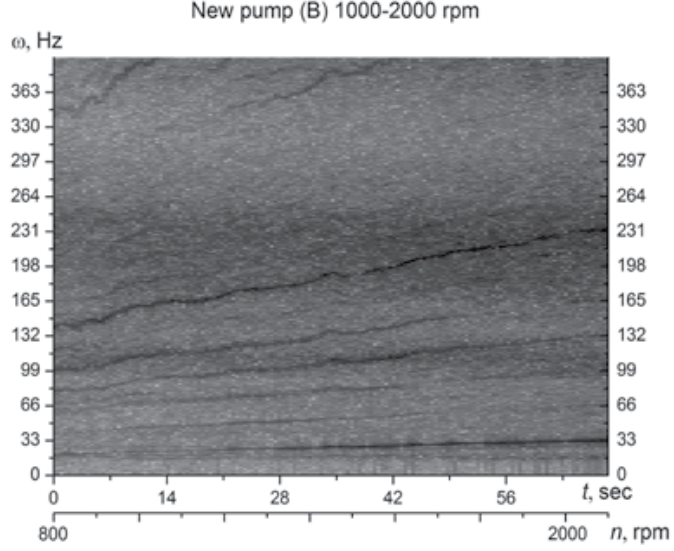

b

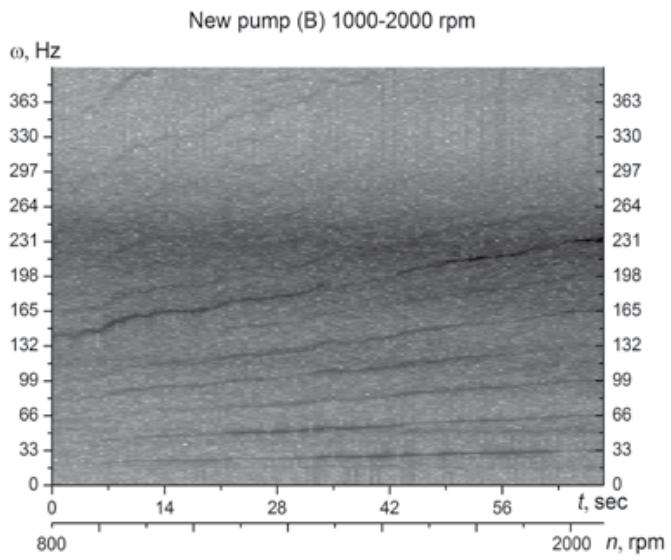

d



f

Fig. 6. Spectrums $(a, c, e)$ and spectrograms $(b, d, f)$ of vibration accelerations of the fire pump, which has defect (unfasten shaft) in the vertical $(a, b)$, the axial $(c, d)$ and horizontal $(e, f)$ directions

Fig. 7 shows the spatial trajectory of the acceleration vector at the point of the pump with the presence of internal defect. Apart from previously marked domination of the vibration in the axial direction, the phenomenon of changing of the angle of orientation of the ellipse tra- jectory in the YZ projection are presented. Thus, the angle of the inclination of major axis of ellipse to the axial direction is around $80^{\circ}$ that significantly differs from the previously obtained value of $55^{\circ}$ for the non-defected fire pump. 


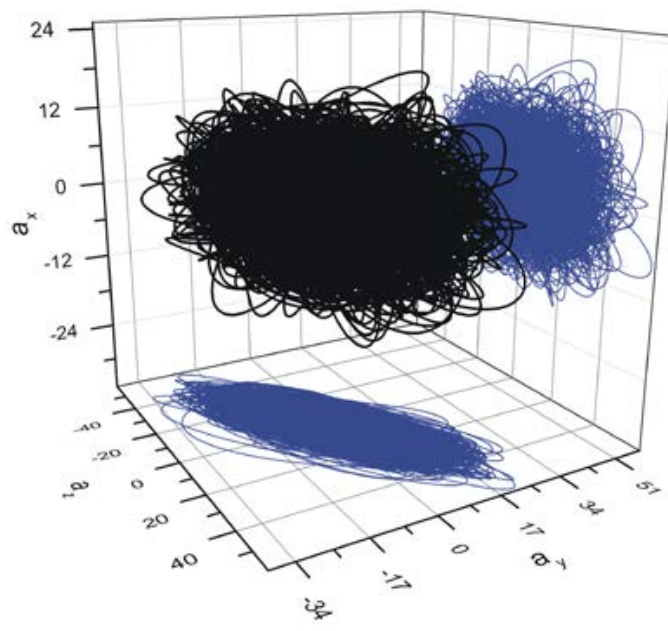

$\mathrm{a}$

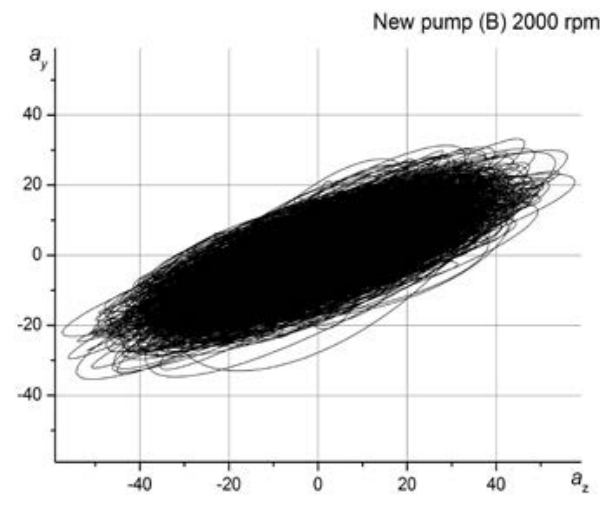

C

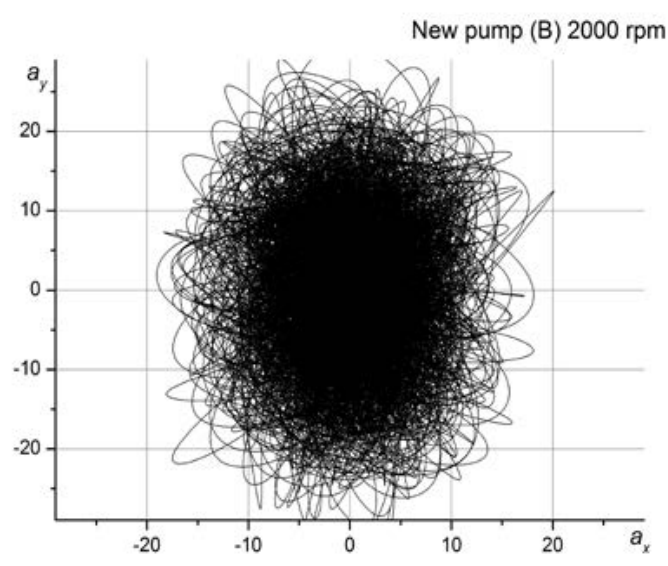

$\mathrm{b}$

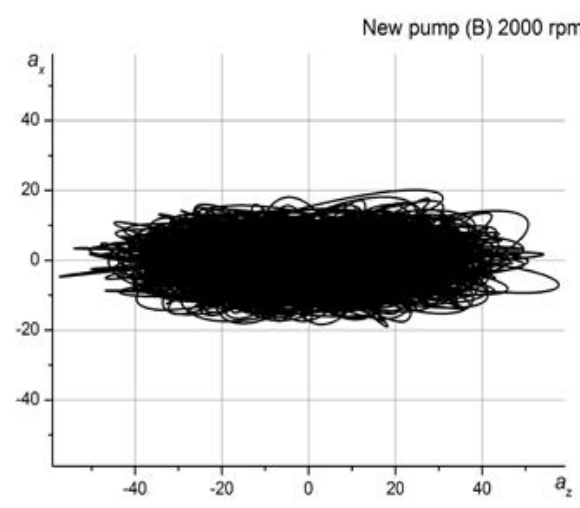

d

Fig. 7. Spatial trajectory of vibrations acceleration vector of the fire pump, which has defect (unfasten shaft) (pump rotor angular velocity is about $2000 \mathrm{rpm}$ ) - the trajectory in space, $(b, c, d)$ - its XY; YZ; XZ projections

\section{Conclusions}

Thus, in the current experimental studies of vibrations of centrifugal fire pump PN-40UV without defects and with unfastened shaft in a bearing seat. A spectral analysis of vibration and investigation of the forming of spatial trajectory of vibration acceleration vector have been carried out. It should be noted that obtained results on spatial trajectories as well as conclusions about levels of vibrations magnification cannot be generalized for other types of a centrifugal pump and should be used for diagnostics of the PN-40 UV fire pump which is installed in an emergency vehicle.

It was determined that the spectrum of vibrations of the pump with mentioned type of defect have fractional harmonics ( 0.5 and 3.5 of the rotor rotation). The changing in the spatial orientation of the vibration of the defected pump has been defined. So, a non-defected pump has vibrations with domination in the vertical direction, but a defected fire pump vibrations are axially oriented.

These vibrational symptoms of the analyzed type of hidden defects can be used in the procedures of fire pumps technical diagnostics. A usage of this technique will im- prove system technical check-up and preventive maintenance, that, on the one hand, leads to a reduction of the idle standing of fire equipment that are associated with untimely repair work, and on the other hand, will prevent sudden failures of pumps in operation.

\section{References}

1. ISO-10816-1-6 Mechanical vibration - Evaluation of machine vibration by measurements on non-rotating Parts.

2. Vodka A.A. Measurement system on the base of MEMS sensor, A.A. Vodka, A.I. Trubaiev, Yu.N. Ulianov, in: "Bulletin of the Volodymyr Dal Eastern Ukrainian National University", Lugansk, 2012, Vol. 1 Issue 9, pp. 140-147.

3. Ulianov Yu.N. A system for vibration acceleration measurements on the base of MEMS sensor, A.A. Vodka, A.I. Trubaiev, Yu.N. Ulianov, in: Proceedings of the III International Scientific conference The problems of the transport technic and logistics, Evpatoria, Ukraine, 3-8 may 2012, p. 191.

4. Larin O.M., A diagnosis of the technical state of the support of fire pump by the spectra of its vibrations, O.M. Larin, O.O. Larin, V.V. Chigrin, "Science and Education a New Dimension: Natural and Technical Science", Vol. 8 (2013), pp. 112-116. 
5. Brigham, E. Oran, The fast Fourier transform and its applications, Englewood Cliffs Prentice Hall, New Jersey, 1988.

6. Oppenheim A.V.; Schafer R.W., Buck J.R., Discrete-time signal processing, Upper Saddle River, N.J.: Prentice Hall, 1999.

7. Jont B., Allen Short Time Spectral Analysis, Synthesis, and Modification by Discrete Fourier Transform, "IEEE Transactions on Acoustics, Speech, and Signal Processing" Vol. 25 Issue 3, pp. 235-238.

Aleksandr Larin - Professor of the Department of General, Emergency and Rescue Engineering of the National University of Civil Defence of Ukraine, Doctor of Science, Professor. Sphere of scientific interests: operation and repair of vehicles, fire and emergency engineering, diagnostics of fire and rescue equipment. The author (co-author) of more than 200 scientific publications.
Aleksii Larin - Associated Professor of the Department of Dynamics and Strength of Machines of the National Technical University "Kharkiv Polytechnical Institute", $\mathrm{PhD}$. Sphere of scientific interests: prediction of the reliability of mechanical systems, nonlinear and random vibration of machines and machine elements, vibration measurements, technical diagnostics. The author (co-author) of more than 70 scientific publications.

Igor Ushapivsky - Head of the department of emergency response of the General Directorate of State Service for Emergency Situations of Ukraine in Lviv region. Sphere of scientific interests: operational activities in emergency elimination, fire engineering, diagnostics of fire and rescue equipment. 